\title{
Soil aluminium toxicity in New Zealand pastoral farming - a review
}

\author{
J.D. MORTON ${ }^{1}$ and J.L. MOIR ${ }^{2}$ \\ ${ }^{1}$ MortonAg, 27 Waimakariri Drive, Napier 4110, New Zealand \\ ${ }^{2}$ Lincoln University, PO Box 84, Lincoln, Canterbury, New Zealand \\ mortonag1@gmail.com
}

\begin{abstract}
As most New Zealand pastoral soils are acidic, aluminium $(\mathrm{Al})$ can be present at high concentrations and restrict plant root growth and shoot yield. In field trials, $\mathrm{Al}$ toxicity in white clover has been associated with $\mathrm{CaCl}_{2}$-extractable soil $\mathrm{Al}$ levels of 3-5 ppm or exchangeable soil $\mathrm{KCl}$-extractable levels of 1-2 $\mathrm{me} / 100 \mathrm{~g}$, when soil $\mathrm{pH}$ levels were below 5.5-5.7 in the top $75 \mathrm{~mm}$. Lucerne is less tolerant of Al toxicity than white clover and ryegrass, which in turn are less tolerant than Lotus spp., arrow leaf, subterranean, Caucasian, Persian and gland clovers, and naturalised adventive annuals such as cluster, haresfoot, striated and suckling clovers. Soil Al toxicity generally increases with soil depth. Soil $\mathrm{pH}$ is a reliable indicator of soil Al and, on average, can be increased by 0.1 units/tonne/ha of applied lime to reduce soil $\mathrm{Al}$ to below the toxic range. Lime application is the most effective strategy where it can be ground-applied. A key limitation of groundapplied lime to reduce $\mathrm{Al}$ toxicity is that its movement down the soil only occurs slowly except in high rainfall areas. Soil $\mathrm{Al}$ and $\mathrm{pH}$ levels and legume content in hill soils varies according to slope and aspect and there is an opportunity to differentially apply lime by air to areas with low soil $\mathrm{pH}$ and more legume, for the best economic return.
\end{abstract}

Keywords: legume, lime, soil aluminium, soil $\mathrm{pH}$

\section{Introduction}

Although it is not an essential element, $\mathrm{Al}$ can have a toxic effect on plant growth through root damage which restricts the ability of the root system to take up water and nutrients. Toxic concentrations of $\mathrm{Al}$ occur when $\mathrm{Al}$ ions are released into the soil solution as acidity increases in New Zealand's mostly acidic soils.

High Al concentrations in soil solution adversely affected legume nodulation (Edmeades et al. 1991). Berenji et al. (2017), in a field trial on a Stony Brown soil in North Canterbury, demonstrated that high $0.02 \mathrm{M} \mathrm{CaCl}_{2}$-extractable soil $\mathrm{Al}$ levels of $15.1 \mathrm{ppm}$ (soil pH 5.2) in the top $75 \mathrm{~mm}$, strongly inhibited the ability of rhizobia to inoculate lucerne; the threshold (above which soil Al has a measurable effect) for effective inoculation was less than $1 \mathrm{ppm} 0.02 \mathrm{M} \mathrm{CaCl}_{2}$ - extractable Al. In contrast, Berenji et al. (2015) found no effect of a $\mathrm{CaCl}_{2}$-extractable soil $\mathrm{Al}$ level of $4.2 \mathrm{ppm}$ (soil pH 5.2) on nitrogen fixation in lucerne, on a Gley soil near Lincoln.

The alleviation of $\mathrm{Al}$ toxicity is one of the several mechanisms by which pasture growth responds to lime as well as increasing the availability of phosphorus (P), molybdenum, nitrogen, and calcium, improving the access of plants to soil moisture and encouraging earthworm and micro-organism activity (Wheeler \& O’Connor 1998).

Extractable Al levels in New Zealand soils have been measured in experiments carried out since the 1980s when $\mathrm{Al}$ toxicity was recognised as one of the major causes of the deleterious effects of soil acidity on plant growth (Jackson \& Edmeades 1985). In more intensive farming systems that are closer to a lime quarry, $\mathrm{Al}$ toxicity can be economically remedied by groundspreading high rates of lime on flat to rolling land. On steeper land where more costly aerial application is required to support lower production and/or the farm is further away from a lime quarry, this solution may not be cost-effective. Therefore, $\mathrm{Al}$ toxicity is still limiting farm production on many hill and high-country soils, mainly through less legume growth.

This paper reviews research carried out on New Zealand pastoral soils where soil Al levels were measured so that a more complete understanding of the role of Al toxicity can be gained. Some management strategies are also outlined on how to counter Al toxicity on soils where blanket liming at high rates cannot be economically carried out to achieve optimum soil $\mathrm{pH}$ and $\mathrm{Al}$ levels over the whole farm.

All quoted soil $\mathrm{Al}$ and $\mathrm{pH}$ levels throughout this paper are from sampling at $0-75 \mathrm{~mm}$ soil depth unless otherwise stated and all soil $\mathrm{pH}$ measurements are water-extractable.

\section{Measurement of soil Al levels in New Zealand}

There are several methods of measuring soil Al levels. The two laboratory extractants most commonly used in New Zealand are $0.02 \mathrm{M} \mathrm{CaCl}_{2}$, designed to mimic the concentration of $\mathrm{Al}$ in soil solution, and $1 \mathrm{M} \mathrm{KCl}$ to provide a measure of exchangeable $\mathrm{Al}$. In a glasshouse trial, Edmeades et al. (1983) extracted soil Al with $0.02 \mathrm{M} \mathrm{CaCl}_{2}$ (Hoyt \& Nyborg 1972) and $1 \mathrm{M} \mathrm{KCl}$ (McLean 1965) and also measured the concentration of Al in soil solution (Adams \& Lund 1966). They reported that solution $\mathrm{Al}$ (the form immediately available to the 
roots) was reduced at high rates of $\mathrm{P}$ application, but there was no effect of $\mathrm{P}$ on the amount of $\mathrm{Al}$ extracted by $\mathrm{CaCl}_{2}$ or $\mathrm{KCl}$.

Hume et al. (1988) found in a glasshouse trial with white clover, that yields were more closely related to $0.02 \mathrm{M} \mathrm{CaCl}_{2}$-extractable $\mathrm{Al}$ than $1 \mathrm{M} \mathrm{KCl}$-extractable $\mathrm{Al}$ or $\mathrm{pH}$ in seven strongly acid topsoils and subsoils.

\section{Diagnostic criteria for $\mathrm{Al}$ toxicity in white clover}

In a glasshouse trial (Edmeades et al. 1983), Al toxicity in white clover was estimated to be associated with soil levels greater than 3 and 5 ppm for $0.02 \mathrm{M} \mathrm{CaCl}_{2}-$ extractable soil $\mathrm{Al}$, greater than 1 and $2 \mathrm{me} / 100 \mathrm{~g}$ for $1 \mathrm{M} \mathrm{KCl}$-extractable $\mathrm{Al}$, and $\mathrm{Al}$ solution activity greater than 9-15 $\mu \mathrm{M}$ for the Waitakarere Granular and Marua Brown soils, respectively. Critical values of soil $\mathrm{pH}$ ranged from 4.4-4.7, but the ionic strength of soil solutions from the pots was much greater than that found in the field, lowering the critical soil $\mathrm{pH}$ values. This difference in ionic strength highlighted a major limitation of glasshouse studies for developing diagnostic criteria. In the presence of adequate soil P, higher Al concentrations in soil solution of greater than 30-40 $\mu \mathrm{M}$ were reported as being toxic (Edmeades \& Wheeler 1985).

In another glasshouse trial, Hume et al. (1988) reported data showing $0.02 \mathrm{M} \mathrm{CaCl}_{2}$-extractable soil $\mathrm{Al}$ levels below about $3.3 \mathrm{ppm}$ did not cause reduced white clover growth, and conversely that levels higher than this may have been toxic.

Field trial data associated with legume or pasture production responses to lime to validate the critical soil Al levels for toxicity are limited. In pastures with white clover as the dominant legume, Morton et al. (2005) measured significant pasture production and legume cover responses $(\mathrm{P}<0.05)$ to lime on a Waipawa Pallic hill soil, that corresponded to reductions in $\mathrm{CaCl}_{2}$ extractable soil $\mathrm{Al}$ from 3.02 to $1.47 \mathrm{ppm}$ on a south aspect-easy slope, and 5.23 to $2.85 \mathrm{ppm}$ on a south aspect-steep site.

\section{Effect of Al toxicity on different pasture species}

White and red clover and to a lesser extent subterranean clover are the most commonly sown legumes in New Zealand and are all sensitive to high $\mathrm{Al}$ concentrations in soil solution, although subterranean clover was reported as being more tolerant than white or red clover (Edmeades et al. 1991). Lucerne has been reported to be more intolerant of high soil Al levels than white and subterranean clover or ryegrass (Munns 1965; Helyar \& Anderson 1971; Andrew et al. 1973). Wheeler et al. (1992) reported from glasshouse trials that ryegrass had a similar or slightly higher tolerance to $\mathrm{Al}$ in soil solution than white clover while browntop showed more tolerance than either species.
In a glasshouse trial, Maxwell et al. (2012) showed that subterranean clover and naturalised, adventive annual clovers (cluster, haresfoot, striated and suckling) are highly adapted to soil environments with high Al (3.7 ppm $\mathrm{CaCl}_{2}$-extractable)/low soil pH (5.2)). Caradus et al. (2001) monitored the growth of fifteen legume species for 3 years on three Otago upland Brown and Pallic soils with $\mathrm{CaCl}_{2}$-extractable soil $\mathrm{Al}$ levels of 11 (soil pH 5.1), 45 (soil pH 4.6) and 70 (soil pH 4.8) ppm, and found that Lotus corniculatus, Lotus pedunculatus and Caucasian clover were more tolerant of soil Al toxicity than commercial white clover cultivars and an alsike clover. There was no difference in tolerance to soil Al toxicity between the commercial white clover cultivars and the types selected for Al susceptibility or tolerance. These researchers concluded that optimising the performance of Al-tolerant legumes on acid soils will be a more productive strategy than breeding for Altolerance in white clover.

In a glasshouse trial, Moir et al. (2016), using an acid high-country Brown soil with an initial $\mathrm{CaCl}_{2}$ extractable soil $\mathrm{Al}$ of $14 \mathrm{ppm}$ and $\mathrm{pH}$ of 5.1, examined optimum soil $\mathrm{Al}$ and $\mathrm{pH}$ ranges of twelve pasture perennial and annual legumes. Plants with high tolerance thresholds of $\mathrm{CaCl}_{2}$-extractable soil $\mathrm{Al}$ levels of 7-8 ppm (optimum soil pH 5.3-6.5) were tagasaste (tree lucerne), Lotus pedunculatus, Persian and gland (aerial seeding, self- regenerating annual) clovers and falcata lucerne. Arrow leaf clover had the lowest soil Al threshold for tolerance of $2 \mathrm{ppm}$ (optimum soil $\mathrm{pH}$ 5.76.7) with strawberry, white, balansa, subterranean and Caucasian clovers and lucerne intermediate at 3-5 ppm (optimum soil pH 5.4-7.5).

\section{Relationship between soil $\mathrm{Al}$ and $\mathrm{pH}$}

Soil Al would be expected be dependent on soil $\mathrm{pH}$ and this relationship has been confirmed from several trials. McIntosh \& Backholm (1981) measured a moderately strong inverse linear relationship $\left(\mathrm{R}^{2}=0.58\right)$ between soil $\mathrm{pH}$ (4.4-5.2) and exchangeable soil Al (KClextractable) levels at 54 sites in the Otago uplands where values ranged from 1 to $12 \mathrm{me} / 100 \mathrm{~g}$. $\mathrm{CaCl}_{2}$-extractable soil $\mathrm{Al}$ was also positively linearly correlated with annual rainfall $\left(\mathrm{R}^{2}=0.64\right)$ probably because more base cations were leached thereby increasing the amount of $\mathrm{Al}$ on the soil exchange sites.

In a laboratory study, three soils (Taupo Pumice, Matapiro and Tokomaru Pallic) with $\mathrm{pH}$ levels of 5.4, 5.2 and 5.4, respectively, had mean solution $\mathrm{Al}$ concentrations above the critical toxicity range of 30 $40 \mu \mathrm{M}$ (Edmeades \& Wheeler 1985).

On a moist North Island hill-country site, During et al. (1984) found that increasing soil $\mathrm{pH}$ from 5.0 to 5.4 on Kaawa and Kapamahunga Brown soils and from 5.3 to 5.9 on a Niake Granular soil decreased monomeric 
Al (molecular Al that can combine with others of the same kind to form a polymer extracted by $5 \mathrm{mM}$ $\mathrm{CaCl}_{2}$ solution, Okura et al. 1962) from 0.78 and 0.32 , respectively, to less than $0.1 \mu \mathrm{g} / \mathrm{ml}$.

At two field trial sites on a Marua Brown hill soil, Edmeades et al. (1984a) measured $\mathrm{CaCl}_{2}$-extractable soil $\mathrm{Al}$ levels of 5.3 and $7.1 \mathrm{ppm}$ corresponding to a soil $\mathrm{pH}$ of 5.2. The same authors reported a curvilinear inverse relationship between soil $\mathrm{pH}$ and $\mathrm{Al}$ levels on a Mahoenui Brown hill soil.

Wheeler (1998) reported that exchangeable soil $\mathrm{Al}$ (KCl-extractable) levels in the top $50 \mathrm{~mm}$ of a Mangatua Pallic soil decreased from 0.8 to $0.6 \mathrm{me} / 100 \mathrm{~g}$ soil as soil $\mathrm{pH}$ increased from 5.3 to 6.3 .

On four low rainfall (mean annual rainfall $800 \mathrm{~mm}$ ) hill-country sites on a Waipawa Pallic soil, increases in soil $\mathrm{pH}$ from an initial 5.4-5.6 to 6.3-6.7 resulted in a decline in average $\mathrm{CaCl}_{2}$-extractable soil $\mathrm{Al}$ from an initial $1.45-5.23 \mathrm{ppm}$ to $0.13-0.45 \mathrm{ppm}$ (Morton et al. 2005).

Moir \& Moot (2010) measured a strong inverse sigmoidal relationship $\left(\mathrm{R}^{2}=0.73\right)$ between soil $\mathrm{pH}$ and exchangeable soil $\mathrm{Al}$ ( $\mathrm{KCl}$-extractable) on a highcountry Brown soil in North Canterbury under a low mean annual rainfall of $600 \mathrm{~mm}$. The Al level of 1 $\mathrm{me} / 100 \mathrm{~g}$ which was at the lower end of the range of 1-2 me $/ 100 \mathrm{~g}$ associated with $\mathrm{Al}$ toxicity (Edmeades et al. 1983), corresponded to a soil $\mathrm{pH}$ of 5.5.

Moir \& Moot (2014) also reported strong inverse exponential and polynomial relationships $\left(\mathrm{R}^{2}=0.69\right.$ 0.85 ) between soil $\mathrm{pH}$ and $\mathrm{CaCl}_{2}$-extractable $\mathrm{Al}$ levels on three South Island high-country Brown soils under low mean annual rainfall of $600 \mathrm{~mm}$. Soil Al levels were low (1-2 ppm) within the soil $\mathrm{pH}$ range of 6.0-7.0 but rose sharply to 2-3 ppm when $\mathrm{pH}$ fell below 5.7. At a $\mathrm{pH}$ of 5.5, levels increased to 5.0, 2.5 and $4 \mathrm{ppm}$, respectively, at the three sites. There was considerable variation in the increase in soil $\mathrm{Al}$ per decrease in $\mathrm{pH}$ measuring 3-4 ppm Al/0.1 pH unit decrease at two sites but $1 \mathrm{ppm} \mathrm{Al} / 0.1 \mathrm{pH}$ unit decrease at the other site.

Whitley et al. (2016) also found a moderately strong inverse exponential relationship $\left(\mathrm{R}^{2}=0.65\right)$ between soil $\mathrm{pH}$ and $\mathrm{CaCl}_{2}$-extractable $\mathrm{Al}$ and the variability in the relationship was partially explained by soil order with Brown soils having the highest and Pumice and Allophanic soils the lowest soil Al levels.

Venter (2017) reported strong relationships between soil $\mathrm{pH}$ and $\mathrm{Al}$ saturation on the cation exchange sites on Brown soils from North Otago at both $0-150 \mathrm{~mm}$ $\left(\mathrm{R}^{2}=0.97\right)$ and $150-300 \mathrm{~mm}\left(\mathrm{R}^{2}=0.79\right)$ depths.

The above research results confirm that extractable soil $\mathrm{Al}$ is consistently increased as soil $\mathrm{pH}$ declines and the soil becomes more acid. Conversely an increase in soil $\mathrm{pH}$ reduces soil extractable $\mathrm{Al}$ levels.

\section{Effect of liming on soil Al}

From the previous section, it follows that lime application to increase soil $\mathrm{pH}$ will also reduce extractable soil Al. This effect is verified experimentally by field research results as shown in Table 1.

From the trials where soil $\mathrm{Al}$ has been extracted with $\mathrm{CaCl}_{2}, 0.5 \mathrm{t}$ lime/ha (Morton et al. 2005), 3-5 t lime/ha (Kearney et al. 2010) and 1-8 t lime/ha (Moir \& Moot 2014) were required to reduce the levels below the critical range of 3-5 ppm associated with $\mathrm{Al}$ toxicity for white clover (Edmeades et al. 1983). The increase in soil Al levels from low rates of lime below $1 \mathrm{t} / \mathrm{ha}$ at one site (Table 1) (Moir \& Moot 2014) could be attributed to trial variability. The rate of lime required to reduce extractable soil Al levels below the critical range associated with $\mathrm{Al}$ toxicity was not related to initial soil $\mathrm{Al}$ levels. Soil $\mathrm{CaCl}_{2}$-extractable and $\mathrm{KCl}$-extractable Al levels reported by Edmeades et al. (1984a) and Moir \& Moot (2010), respectively, were already below the critical ranges of 3-5 ppm and 1-2 me/100g associated with soil Al toxicity (Edmeades et al. 1983) before liming, so no estimate of the required rate of lime to mitigate soil Al toxicity could be obtained. The exchangeable soil $\mathrm{Al}$ (KCl-extractable) levels for the nil lime treatment reported by Wheeler (1998) were also below the critical range associated with $\mathrm{Al}$ toxicity, but higher exchangeable soil Al levels lower in the soil profile were ameliorated by liming.

The above estimates of the rate of lime required to reduce extractable soil $\mathrm{Al}$ from specific levels to below the critical ranges associated with $\mathrm{Al}$ toxicity are extremely variable. Therefore, it is best to apply lime at $1 \mathrm{t} / \mathrm{ha}$ to increase soil $\mathrm{pH}$ by 0.1 units (Morton \& Roberts 2016) with a target soil $\mathrm{pH}$ of 5.5 and above, when the toxic effects of soil $\mathrm{Al}$ on white clover growth are mainly alleviated.

\section{Effect of soil Al on legume and pasture production}

The effect of reducing extractable soil Al levels by liming to increase legume and pasture production has been measured in several field trials.

During et al. (1984) reported that reducing monomeric $\mathrm{Al}$ levels $\left(5 \mathrm{mM} \mathrm{CaCl} \mathrm{Cl}_{2}\right.$-extractable) from $0.78 \mu \mathrm{g} / \mathrm{ml}$ (soil pH 5.0) on a Brown soil and $0.32 \mu \mathrm{g} /$ $\mathrm{ml}$ (soil pH 5.1) on a Granular soil, to less than 0.1 $\mu \mathrm{g} / \mathrm{ml}$ on both soils, significantly $(\mathrm{P}<0.05)$ increased pasture production measured in April and August by 21 and $25 \%$, respectively.

Edmeades et al. (1984a) on two field trial sites that had initial $\mathrm{CaCl}_{2}$-extractable soil Al levels of 5.3 and $7.1 \mathrm{ppm}$ (both with soil pH 5.2), found that $2.5 \mathrm{t} / \mathrm{ha}$ of lime significantly increased pasture production by 10 and $13 \%$, respectively (Edmeades \& Wheeler 1985) over 3 years on ryegrass/white clover and browntopdominant pastures located on a Marua Brown hill 
soil. On a Mahoenui Brown hill soil at a lower $\mathrm{CaCl}_{2}$ extractable soil Al level of $1.4 \mathrm{ppm}$ (soil pH 5.4), rates of lime up to $10 \mathrm{t} / \mathrm{ha}$ also significantly increased pasture production, but this was attributed to liming stimulating grass growth due to the release of organic N (Edmeades et al. 1984a).

On a Pallic soil, Wheeler (1998) measured a significant $(\mathrm{P}<0.05)$ 4-year mean pasture production response of $10 \%$ by reducing exchangeable soil $\mathrm{Al}$ (KCl-extractable) levels from 0.3 to $0.1 \mathrm{me} / 100 \mathrm{~g}$ in the top $50 \mathrm{~mm}$ of soil. Although the soil Al level at this depth was below the critical range of $1-2 \mathrm{me} / 100 \mathrm{~g}$ associated with $\mathrm{Al}$ toxicity for white clover (Edmeades et al. 1983), Al levels at 100-200 mm depth were in the critical range for Al toxicity and $5 \mathrm{t} / \mathrm{ha}$ of lime reduced these levels to below this range. However, Wheeler (1998) considered that the other mechanisms of lime response at this site were an increase in pasture $\mathrm{N}$ uptake of $38 \mathrm{~kg} \mathrm{~N} / \mathrm{ha}$ during the last 3 years from mineralisation of soil organic $\mathrm{N}$ and an increase in the availability of $\mathrm{P}$ at some harvests.

On three high-country Pallic and Brown soils over 3 years, Caradus et al. (2001) reported that legume production was highest at the low altitude site with the lowest $\mathrm{CaCl}_{2}$-extractable soil Al level of $10.6 \mathrm{ppm}$ (soil
$\mathrm{pH}$ 5.1) and least at the highest altitude site with the intermediate level of $45.1 \mathrm{ppm}$ (soil pH 4.6).

Morton et al. (2005) measured the effect of soil $\mathrm{Al}$ on pasture production at four sites with different slopes and aspects on dry North Island hill-country. On the north aspect-easy slope site with an initial soil $\mathrm{pH}$ of 5.6, there was no significant increase in legume cover and pasture production $(\mathrm{P}>0.05)$ over 3 years from reducing $\mathrm{CaCl}_{2}$-extractable soil $\mathrm{Al}$ from 1.45 to $0.13 \mathrm{ppm}$. There was also no significant response in pasture production $(\mathrm{P}>0.05)$ over 3 years by reducing soil $\mathrm{Al}$ from 4.48 to $0.22 \mathrm{ppm}$ on the north-steep site (initial soil pH 5.4). The north-easy site had soil Al levels below the critical range of 3-5 ppm associated with Al toxicity (Edmeades et al. 1983) and the north-steep site, with a high initial soil Al level had a lower ground cover of legume than the north-easy site (17 versus $44 \%$ ). Reducing soil Al levels from 3.02 to $0.32 \mathrm{ppm}$, significantly $(\mathrm{P}<0.05)$ increased pasture production by $14 \%$ over 2 years on the south-easy site (initial soil $\mathrm{pH}$ 5.4) despite the initial level being just within the critical range associated with $\mathrm{Al}$ toxicity. The highest initial soil Al levels (5.23 ppm) were on the south-steep site (initial soil $\mathrm{pH}$ 5.4) which also had a high legume cover (36\%), and reducing soil Al to 0.45 ppm significantly $(\mathrm{P}<0.05)$ increased pasture

Table $1 \quad$ Effect of rate of liming on soil extractable Al levels.

\begin{tabular}{|c|c|c|c|c|c|}
\hline \multirow[t]{2}{*}{ Soil Order } & \multirow[t]{2}{*}{ Rate(s) of lime (t/ha) } & \multicolumn{3}{|c|}{ Extractable soil Al } & \multirow[t]{2}{*}{ Reference } \\
\hline & & Method & Unlimed & Limed $^{\star}$ & \\
\hline Brown & 0,3 & $5 \mathrm{mM} \mathrm{CaCl}{ }_{2}$ & $0.78 \mu \mathrm{g} / \mathrm{ml}$ & $<0.1 \mu \mathrm{g} / \mathrm{ml}$ & During et al. (1984) \\
\hline Granular & 0,3 & $5 \mathrm{mM} \mathrm{CaCl}_{2}$ & $0.32 \mu \mathrm{g} / \mathrm{ml}$ & $<0.1 \mu \mathrm{g} / \mathrm{ml}$ & During et al. (1984) \\
\hline Brown & $0,1.25,2.5$ & $0.01 \mathrm{M} \mathrm{CaCl}_{2}$ & 1.4 ppm & 0.15 ppm & Edmeades et al. (1984a) \\
\hline Pallic & $0,2.5,5,7.5,10$ & $1 \mathrm{M} \mathrm{KCl} \mathrm{0-50} \mathrm{mm}$ & $0.30 \mathrm{me} / 100 \mathrm{~g}$ & $<0.1 \mathrm{me} / 100 \mathrm{~g}$ & Wheeler (1998) \\
\hline \multirow[t]{5}{*}{ Pallic } & $0.5^{\star *}$ & $0.02 \mathrm{M} \mathrm{CaCl}_{2}$ & $3.55 \mathrm{ppm}$ & $2.21 \mathrm{ppm}$ & Morton et al. (2005) \\
\hline & $1^{*}$ & & $3.55 \mathrm{ppm}$ & $1.66 \mathrm{ppm}$ & \\
\hline & $2^{*}$ & & $3.55 \mathrm{ppm}$ & $1.02 \mathrm{ppm}$ & \\
\hline & $4^{*}$ & & $3.55 \mathrm{ppm}$ & $0.50 \mathrm{ppm}$ & \\
\hline & $8^{*}$ & & 3.55 ppm & $0.28 \mathrm{ppm}$ & \\
\hline Pallic/Brown & $3-5$ & $0.02 \mathrm{M} \mathrm{CaCl}_{2}$ & 4.90 ppm & $1.2 \mathrm{ppm}$ & Kearney et al. (2010) \\
\hline (average of 3 farms) & & 0-150 mm & & & \\
\hline Brown stony & $0,2,4,8$ & $1 \mathrm{M} \mathrm{KCl}$ & $0.9 \mathrm{me} / 100 \mathrm{~g}$ & $0.1 \mathrm{me} / 100 \mathrm{~g}$ & Moir \& Moot (2010) \\
\hline \multirow[t]{3}{*}{ Brown stony } & 2 & $0.02 \mathrm{M} \mathrm{CaCl}_{2}$ & $3 \mathrm{ppm}$ & $2.2 \mathrm{ppm}$ & Moir \& Moot (2014) \\
\hline & 4 & & $3 \mathrm{ppm}$ & $1.2 \mathrm{ppm}$ & \\
\hline & 8 & & $3 \mathrm{ppm}$ & $0.5 \mathrm{ppm}$ & \\
\hline \multirow[t]{2}{*}{ Brown } & 3 & $0.02 \mathrm{M} \mathrm{CaCl}_{2}$ & 5 ppm & $2.2 \mathrm{ppm}$ & Moir \& Moot (2014) \\
\hline & 5 & & 5 ppm & $2.6 \mathrm{ppm}$ & \\
\hline \multirow[t]{3}{*}{ Brown } & $0,0.13,0.25,0.5$ & $0.02 \mathrm{M} \mathrm{CaCl}_{2}$ & $3.1 \mathrm{ppm}$ & $3.5 \mathrm{ppm}$ & Moir \& Moot (2014) \\
\hline & 1 & & $3.1 \mathrm{ppm}$ & 1.5 ppm & \\
\hline & 2,4 & & $3.1 \mathrm{ppm}$ & $1.3 \mathrm{ppm}$ & \\
\hline
\end{tabular}

*Soil Al value for limed, where there is more than one rate, is for the highest rate applied. ${ }^{\star \star}$ Mean of all aspects and slopes. 
production by $18 \%$ over 2 years.

On a high-country stony Brown soil, Moir \& Moot (2010) reduced exchangeable soil Al (KCl-extractable) levels from 0.9 to $0.1 \mathrm{me} / 100 \mathrm{~g}$ and measured no increase in lucerne DM production. This lack of growth response was probably because initial exchangeable soil Al levels were below the critical range of 1-2 me/100g associated with $\mathrm{Al}$ toxicity (Edmeades et al. 1983 ) and the shallow depth of topsoil limited growth.

In a 6 year field trial on a high-country Brown soil with $\mathrm{CaCl}_{2}$-extractable soil $\mathrm{Al}$ levels of $7 \mathrm{ppm}$ (soil pH 5.2), Berenji et al. (2017) reported declining lucerne yield (4.2 t DM/ha in Year 1 to $1.0 \mathrm{t} \mathrm{DM} / \mathrm{ha}$ in Years 4 and 6) and depressed fine root growth. In contrast, the more Al-tolerant Caucasian clover persisted and yielded $1.7 \mathrm{t} \mathrm{DM} / \mathrm{ha}$ in Year 1 increasing to $4.0 \mathrm{t} \mathrm{DM} / \mathrm{ha}$ in Year 4 and $7.7 \mathrm{t} \mathrm{DM} /$ ha in Year 6. Although the trial was carried out for several years, only initial soil Al levels were reported so it was not possible to use these yield data to identify the critical Al level associated with $\mathrm{Al}$ toxicity for these legume species.

Increasing soil $\mathrm{pH}$ to above 5.5 by liming is a simple and reasonably effective method of ensuring that the toxic effects from soil Al have been alleviated. Extractable soil Al levels associated with Al toxicity occurred at soil $\mathrm{pH}$ levels below 5.5 in most of the reported trials. Furthermore, the relationship between soil $\mathrm{pH}$ and pasture production (Edmeades et al. 1984b) is based on much more data than exists for that between soil $\mathrm{Al}$ and pasture production.

\section{Effect of soil depth on soil Al}

In some soils, exchangeable Al levels can increase with depth of sampling (Wheeler 1998; Moir \& Moot 2010, 2014; Whitley et al. 2016). Higher extractable soil Al in lower soil horizons often causes plant roots to branch out horizontally when they encounter toxic levels (Moir $\&$ Moot 2010). This lack of root penetration can result in moisture stress because plants are unable to extract water from lower in the soil profile. The movement of surface-applied lime into the $0-75 \mathrm{~mm}$ soil layer to ameliorate acid and toxic $\mathrm{Al}$ conditions under low mean annual rainfall of $600 \mathrm{~mm}$, as indicated by reductions in $\mathrm{CaCl}_{2}$-extractable soil $\mathrm{Al}$ levels, was measured within 5 years of applying $2 \mathrm{t} / \mathrm{ha}$ of lime at one site, within 3 years of applying $3 \mathrm{t} / \mathrm{ha}$ of lime at a second site and within 7 years of applying $1 \mathrm{t} / \mathrm{ha}$ of lime at a third site (Moir \& Moot 2014). At 75-150 mm soil depth, and only within 5 years of applying 8 t/ha of lime at one site were soil Al levels reduced to below the range associated with $\mathrm{Al}$ toxicity (Edmeades et al. 1983). Under the same mean annual rainfall, Moir \& Moot (2010) measured a reduction in exchangeable soil Al (KCl-extractable) levels, in October 2008, at $75-150 \mathrm{~mm}$ but not $150-300 \mathrm{~mm}$ soil depth, to below those associated with Al toxicity (Edmeades et al. 1983), from surface-application of 4 and $8 \mathrm{t} / \mathrm{ha}$ of lime in the preceding March. However, increases in soil $\mathrm{pH}$ and decreases in exchangeable soil $\mathrm{Al}$ were measured down to $100-200 \mathrm{~mm}$ soil depth 5 years after 5-10 t lime/ha was applied under a high mean annual rainfall of $1400 \mathrm{~mm}$ (Wheeler 1998). Incorporation of lime into the soil during cultivation should reduce soil Al levels at lower soil depths more quickly than surfaceapplied lime. However, because direct-drilling is often used to sow pasture, conserve soil moisture and reduce costs (e.g. Kearney et al. 2010), lime cannot always be incorporated lower into the soil profile where soil Al levels are higher.

\section{Soil moisture and $\mathrm{Al}$ toxicity}

There have been two reports of the effect of soil Al toxicity being less under moister soil conditions. Jackson \& Gillingham (1985) reported on a glasshouse trial where at adequate soil moisture levels, high soil Al levels had little effect on white clover growth whereas growth was severely limited under conditions of moisture stress. In the field, Wheeler (1998) reported that summer pasture growth did not respond to a high rate of lime in trial replicates where soil was moister but did respond in trial replicates with drier soil. Also, at a low rainfall North Island hill-country site, Morton et al. (2005) reported that clover cover increased three to four-fold where no lime had been applied during a wet summer compared with a dry one, despite a toxic $\mathrm{CaCl}_{2}$-extractable soil Al level of $4.48 \mathrm{ppm}$ on the north aspect/steep slope trial site. A compensatory effect was observed from the successful establishment of white clover in an area such as the Central Otago tussock uplands (P.D. MacDougall pers. comm.) when a low rate of lime $(1 \mathrm{t} / \mathrm{ha})$ was applied to soils with low $\mathrm{pH}$ (4.8-5.0) and high soil $\mathrm{Al}$ (>5 ppm $\mathrm{CaCl}_{2}$-extractable) and under higher rainfall (>1000 mm/year).

\section{Strategies to mitigate soil Al toxicity}

On more intensive farms where lime is relatively cheap to transport and can be ground-applied, application to increase soil $\mathrm{pH}$ into the optimal range of 5.8-6.0 in the top $75 \mathrm{~mm}$ of non-organic soils (Morton \& Roberts 2016) should alleviate any toxic effect of soil Al on pasture growth.

Where lime is expensive to transport and has to be aerially applied on low producing land, it is often not economic to increase soil $\mathrm{pH}$ to a range of 5.5-5.7, which will usually reduce extractable soil Al levels below the critical range associated with $\mathrm{Al}$ toxicity (Edmeades et al. 1983). On dry North Island hill-country, where soil Al levels were in the critical range associated with Al toxicity for white clover on the south aspect-easy slope, the south-steep site and the north-steep site, but 
not the north-easy site (Morton et al. 2005), the most profitable outcome would have been to apply a low rate of lime (0.5-1.0 t/ha) to the south aspects where, on average, sufficient legume cover $(29 \%)$ was present for pasture production responses to be measured, rather than a blanket application. The north-steep site which although high in soil $\mathrm{Al}$, had a lower mean legume cover $(18 \%)$ and pasture production which did not significantly respond to lime. Therefore, in this environment, lime application should be prioritised on land with $\mathrm{CaCl}_{2}$-extractable soil $\mathrm{Al}$ levels greater than $3 \mathrm{ppm}$ or KCl-extractable levels greater than $1 \mathrm{me} / 100 \mathrm{~g}$ $(\mathrm{pH}<5.5)$ and legume cover greater than $20 \%$.

As noted earlier, these strategies will not overcome $\mathrm{Al}$ toxicity in the subsoil as there is limited movement of surface-applied lime down the profile.

\section{Establishment of Al-sensitive legumes}

On a previously oversown tussock grassland upland site in Central Otago dominated by browntop, Yorkshire fog, crested dogstail and sweet vernal with a small white clover component, Stevens et al. (2014) could not measure a significant $(\mathrm{P}>0.05)$ pasture production response to lime over 4 years at a high soil $\mathrm{CaCl}_{2}-$ extractable Al level of $17.5 \mathrm{ppm}$ and low soil $\mathrm{pH}$ of 5.1 , with a mean annual rainfall of $560 \mathrm{~mm}$. This lack of response to lime could be attributed to the relative tolerance of these unimproved grass species to soil $\mathrm{Al}$ toxicity and reinforces the necessity of having sufficient legume to justify the cost of lime application.

Although it is sensitive to soil Al toxicity, a deep rooting, water-efficient plant such as lucerne can effectively utilise scarce soil water resources provided that sufficient lime is applied to reduce soil Al levels. On three Central Otago dryland flat to rolling farms with low average annual rainfall $(<600 \mathrm{~mm})$ and moderate to high $\mathrm{CaCl}_{2}$-extractable soil $\mathrm{Al}$ levels of 2.6-6.3 ppm and a low pH of 5.2, Kearney et al. (2010) established lucerne producing $4.2 \mathrm{t} \mathrm{DM} /$ ha which outyielded unimproved browntop-dominant (1.5 t DM/ ha) and ryegrass-white clover pastures (2.6 t DM/ha) by about three and two times, respectively, in the first year after sowing. These yields were obtained from an application of 3-5 tlime/ha to reduce soil $\mathrm{CaCl}_{2}$ extractable $\mathrm{Al}$ from an average of 4.9 to $1.2 \mathrm{ppm}$ in the top $150 \mathrm{~mm}$ (Table 1). These sites were mainly on Pallic and Brown soils with moderate to high water holding capacity. This successful establishment of lucerne differed from the low yield and lack of significant response to application of 2-8 $\mathrm{t}$ lime/ha from a similar rainfall, but a exchangeable soil $\mathrm{Al}$ level of $0.9 \mathrm{me} / 100 \mathrm{~g}$ (KCl-extractable), which was below the critical range associated with $\mathrm{Al}$ toxicity, as reported by Moir \& Moot (2010). At this site there was a low water-holding shallow Brown Stony soil which retained much less rainfall than the soils on the farms studied by Kearney et al. (2010). In addition, there was extreme variability in the depth of topsoil according to micro-topography which resulted in poor plant establishment where there was a thin topsoil overlying a coarse gravel base.

\section{Establishment of Al-tolerant legumes}

Where soil and climatic conditions are not suitable for white clover or lucerne, legume species such as Lotus and Caucasian clover (Caradus et al. 2001; Moir et al. 2016; Berenji et al. 2017) or other perennial (e.g. tagasaste, falcata lucerne) and annual (e.g. cluster, haresfoot, striated, suckling, Persian and gland clovers) legumes (Maxwell et al. 2012; Moir et al. 2016), which can survive seasonal dry spells, may be able to be sown.

\section{Conclusions}

1. Soil Al levels can be measured by several laboratory techniques but the best calibrated and most widely used are the $\mathrm{CaCl}_{2}$ and $\mathrm{KCl}$-extractable methods for soil Al.

2. Limited calibration has shown the critical ranges associated with soil $\mathrm{Al}$ toxicity in white clover are 3-5 ppm for $\mathrm{CaCl}_{2-}$ extractable soil $\mathrm{Al}$ and 1-2 me/100g for $\mathrm{KCl}$-extractable exchangeable soil Al.

3. The decrease in soil $\mathrm{Al}$ from liming and the effect of soil $\mathrm{Al}$ on pasture production are difficult to predict. The most robust relationship is between soil $\mathrm{pH}$ and extractable Al levels.

4. Where Al toxicity exists in the topsoil, the best practice is to increase the soil $\mathrm{pH}$ above 5.5 by liming ( $1 \mathrm{t} /$ ha per 0.1 increase in $\mathrm{pH}$ units) which alleviates the negative effect of $\mathrm{Al}$ on the growth of improved legumes and grasses in most situations.

5. Al levels usually increase with soil depth and surface-applied lime is slow to move down through the soil and mitigate toxicity at greater soil depths unless rainfall is high.

6. There is some experimental and field evidence that soil Al has a lesser toxic effect on root and plant growth where soil moisture is adequate, so less lime may be able to used where rainfall is higher $(>1000$ $\mathrm{mm} /$ year).

7. On flat to rolling land close to quarries, incorporation of surface-applied lime through cultivation would be expected to reduce soil Al toxicity at greater soil depth in a cost-effective manner.

8. Where lime has to be aerially applied or transported long distances for land with low production, differential application to areas with low soil $\mathrm{pH}$ $(<5.5)$ /high exchangeable soil $\mathrm{Al}\left(>3 \mathrm{ppm} \mathrm{CaCl}_{2}-\right.$ extractable or $>1 \mathrm{me} / 100 \mathrm{~g} \mathrm{KCl}$-extractable) and greater than $20 \%$ legume cover will be more costeffective than a blanket application. 
9. Successful establishment of white clover and lucerne on dryland farms with high soil Al levels can be difficult even with surface-applied lime but varies according to site water-holding capacity and subsoil acidity.

10. More Al-tolerant perennial legumes such as Lotus spp., Caucasian clover, subterranean clover and naturalised adventive annual legumes such as cluster, haresfoot, striated and suckling clovers or Persian and gland clovers, can be successfully established in soils with high Al levels where it is uneconomic to apply lime.

\section{REFERENCES}

Adams, F.; Lund, Z.F. 1966. Effect of chemical activity of soil solution aluminium on cotton root penetration of acid subsoils. Soil Science 101: 193-198.

Andrew, C.S.; Johnson, A.D.; Sandland, R.L. 1973. Effect of aluminium on the growth and chemical composition of some tropical and temperate pasture legumes. Australian Journal of Agricultural Research 24: 325-339.

Berenji, S.; Moot, D.J.; Moir, J.L.; Ridgway, H.J. 2015. Lucerne dry matter and N-fixation when sown with or without lime and inoculant. Journal of New Zealand Grasslands 77: 109-116.

Berenji, S.; Moot, D.J.; Moir, J.L.; Ridgway, H.J.; Arafat, A. 2017. Dry matter yield, root traits, and nodule occupancy of lucerne and Caucasian clover when sown in acidic soil with high aluminium concentrations. Plant and Soil 416: 227-241.

Caradus, J.R.; Crush, J.R.; Ouyang, L.; Fraser, W. 2001. Evaluation of aluminium-tolerant white clover (Trifolium repens) selections on East Otago upland soils. New Zealand Journal of Agricultural Research 44: 141-150.

During, C.; Jackson, B.L.J.; Dyson, C.B. 1984. Lime effects on hill country. 2. Relation of soil moisture, $\mathrm{pH}$ and aluminium values with pasture yield. New Zealand Journal of Agricultural Research 27: 531535.

Edmeades, D.C.; Smart, C.E.; Wheeler, D.W. 1983. Aluminium toxicity in New Zealand soils: Preliminary results on the development of diagnostic criteria. New Zealand Journal of Agricultural Research 26: 493-501.

Edmeades, D.C.; Feyter, C.; O'Connor M.B. 1984a. Lime and phosphorus requirements for hill country yellow-brown earths. Proceedings of the New Zealand Grassland Association 45: 98-106.

Edmeades, D.C.; Pringle, R.M.; Shannon, P.W.; Mansell, G.P. 1984b. Effects of lime on pasture production on soils in the North Island of New Zealand. New Zealand Journal of Agricultural Research 27: 371-382.
Edmeades, D.C.; Wheeler D.M. 1985. Aluminium toxicity in New Zealand. pp. 50-51. In: Proceedings of a Workshop on Lime in New Zealand Agriculture. New Zealand Ministry of Agriculture and Fisheries, Wellington.

Edmeades, D.C.; Balmey, F.P.C.; Asher, C.J.; Edwards, D.G. 1991. Effects of $\mathrm{pH}$ and aluminium on the growth of temperate pasture species. II. Growth and nodulation of legumes. Australian Journal of Agricultural Research 42: 893-900.

Helyar, K.R., Anderson, A.J. 1971. Effects of lime on the growth of five species on aluminium toxicity and on phosphorus availability. Australian Journal of Agricultural Research 22: 707-721.

Hoyt, D.B.; Nyborg, M. 1972. Use of dilute calcium chloride for the extraction of plant available aluminium and manganese from acid soil. Canadian Journal of Soil Science 52: 163-167.

Hume, L.J.; Ofsoski, N.J.; Reynolds, J. 1988. Influence of $\mathrm{pH}$, exchangeable aluminium and $\mathrm{CaCl}_{2}-$ extractable aluminium on the growth and nitrogenfixing activity of white clover (Trifolium repens) in some New Zealand soils. Plant and Soil 111: 111-119.

Jackson, B.L.J.; Edmeades D.C. 1985. Proceedings of a Workshop on Lime in New Zealand Agriculture. New Zealand Ministry of Agriculture \& Fisheries, Wellington. $71 \mathrm{pp}$.

Jackson, B.L.J.; Gillingham A.G. 1985. Lime-soil moisture relationships pp. 58-60. In: Proceedings of a Workshop on Lime in New Zealand Agriculture. New Zealand Ministry of Agriculture and Fisheries, Wellington.

Kearney, J.K.; Moot D.J.; Pollock K.M. 2010. Onfarm comparison of pasture production in relation to rainfall in Central Otago. Proceedings of the New Zealand Grassland Association 72: 121-126.

Maxwell, T.M.R.; Moir, J.L.; Edwards, G.L. 2012. Sulphur and lime response of four adventive annual clovers grown in a New Zealand high country soil under glasshouse conditions. New Zealand Journal of Agricultural Research 55: 47-62.

McIntosh, P.D.; Backholm, G. 1981. A reconnaissance survey of the Otago Uplands. New Zealand Ministry of Agriculture and Fisheries, Mosgiel, New Zealand. McLean, E.O. 1965. Aluminium. pp. 979-998. In: Methods of soil analysis. Ed. Black, C.A., American Society of Agronomy, Wisconsin, USA.

Moir, J.L.; Moot D.J. 2010. Soil pH, exchangeable aluminium and lucerne yield responses to lime in a South Island high country soil. Proceedings of the New Zealand Grassland Association 72: 191-196.

Moir, J.L.; Moot, D.J. 2014. Medium-term soil pH and exchangeable aluminium response to liming at three high country locations. Proceedings of the New Zealand Grassland Association 76: 41-46. 
Moir, J.L.; Jordan, P.; Moot, D.J. 2016. Phosphorus response and optimum $\mathrm{pH}$ ranges of four pasture legumes grown on an acid upland New Zealand soil under glasshouse conditions. Journal of Soil Science and Plant Nutrition 16: 438-460.

Morton, J.D.; Gray, M.H.; Gillingham, A.G. 2005. Soil and pasture responses to lime on dry hill country. New Zealand Journal of Agricultural Research 48: 143-150.

Morton, J.D.; Roberts A.H.C. 2016. Fertiliser use on New Zealand sheep and beef farms. Fertiliser Association of New Zealand. 52 pp.

Munns, D.N. 1965. Soil acidity and growth of a legume. II. Reactions of aluminium and phosphate in solution and effects of aluminium, phosphate, calcium and $\mathrm{pH}$ on Medicago sativa L. and Trifolium subterranean L. in solution culture. Australian Journal of Agricultural Research 16: 743-755.

Okura, T.; Goto, K.; Yatuyanagi, T. 1962. Forms of aluminium determined by an 8-quinolinolate extraction method. Analytical Chemistry 34: 581-582.

Stevens, D.R.; Thompson, B.R.; Catto, W.D.; Trainor, K.R. 2014. Is nitrogen fertiliser an economic option in hill country? Proceedings of the New Zealand Grassland Association 76: 149-154.
Venter, H.J. 2017. Soil acidity in the Kakanui ranges. In: Science and policy - nutrient management challenges for the next generation. Eds. Currie, L.D.; Hedley M.J. Occasional Report No. 30. Fertiliser and Lime Research Centre, Massey University, Palmerston North, New Zealand. 8 pp. (http://flrc.massey.ac.nz/ publications/html).

Wheeler, D.W.; Edmeades, D.C.; Christie R.A.; Gardner R. 1992. Effect of aluminium on the growth of 34 plant species: A summary of results obtained at low ionic strength culture. Plant and Soil 146: 61-66.

Wheeler, D.W. 1998. Investigations into the mechanisms causing lime response in a grass/clover pasture on a clay loam soil. New Zealand Journal of Agricultural Research 41: 497-515.

Wheeler, D.W.; O'Connor, M.B. 1998. Why do pastures respond to lime? Proceedings of the New Zealand Grassland Association 60: 57-62.

Whitley, A.E.; Moir, J.L., Almond, P.C.; Moot, D.J. 2016. Soil $\mathrm{pH}$ and exchangeable aluminium in contrasting New Zealand high and hill country soils. Hill Country Symposium - Grassland Research and Practice Series 16: 169-172. 